\title{
Global Mean Sea Level Nexus Climate Change: A Dynamic Cointegration and Causality Analyses
}

\author{
Md. Sharif Hossain \\ Department of Accounting and Information Systems, Faculty of Business Studies, University of Dhaka, Dhaka, Bangladesh \\ Email: sharif_hossain@du.ac.bd, sharif_hossain0465@yahoo.com
}

How to cite this paper: Hossain, Md. S. (2021). Global Mean Sea Level Nexus Climate Change: A Dynamic Cointegration and Causality Analyses. Low Carbon Economy, 12, 151-172.

https://doi.org/10.4236/lce.2021.124008

Received: November 5, 2021

Accepted: December 12, 2021

Published: December 15, 2021

Copyright ( 2021 by author(s) and Scientific Research Publishing Inc. This work is licensed under the Creative Commons Attribution International License (CC BY 4.0).

http://creativecommons.org/licenses/by/4.0/

\section{(c) (i) Open Access}

\begin{abstract}
Nowadays, the impact of climate change on the global mean sea level variations is becoming an important issue to the researchers and policy makers as a general concern about environmental degradation is making their way into global policy agenda. That is why, in this paper the principal purpose has been made to investigate the dynamic cointegration and causality relationships between global mean sea level (GMSL) and its determinants. Also another purpose has been made to examine empirically the short-run and long-run effects of climate change, carbon dioxide emissions, energy consumption, trade openness and urbanization on global mean sea level based on the time series data from 1970-2019. From the Augmented Dickey-Fuller (ADF), PhillipsPerron (PP) and Kwiatkowski-Phillips-Schmidt-Shin (KPSS) tests results it is found that all the variables are integrated of order one i.e. I(1). From the bounds test approach, it is found that there exits only one cointegration relationship when GMSL is the dependent variable. From the Granger causality test results of VEC model, it is found that the short-run unidirectional causalities are running from carbon dioxide emissions and energy consumption to global mean sea level, from energy consumption and trade openness to carbon dioxide emissions and from trade openness to energy consumption. It has also been found that the error correction term is statistically significant at any significance level when global mean sea level is treated as endogenous variable indicating that there exists a long-run relationship among the variables in the form of Equation (1). It has also been found that in the short-run the variables temperature, carbon dioxide emissions, and urbanization have significant positive effects while energy consumption and trade openness have significant negative effects on global mean sea level at any significance level. The coefficient of ECM $(-1)$ is statistically significant at any significance level, indicates that speed of adjustment for short-run to research in the long-
\end{abstract}


run equilibrium is statistically significant and within the first year, when global mean sea level is above or below its equilibrium level, it adjusts $66.52 \%$. It has also been found that in the long-run the variables temperature, carbon dioxide emissions, and urbanization have significant positive effects on global mean sea level at any significance level but the variable energy consumption has significant negative effects at $5 \%$ significance level. It is also found that over time higher temperature, and carbon dioxide emissions will increase global mean sea level rapidly. The CUSUM and CUSUMSQ tests results support that the VEC model is stable and can be applied for policy formulation and decision making purposes.

\section{Keywords}

Global Mean Sea Level, Climate Change, Short-Run and Long-Run Effects, Unit Root Tests, Cointegration and Granger Causality Tests

\section{Introduction}

In $18^{\text {th }}, 19^{\text {th }}$, and $20^{\text {th }}$ centuries, the average of the global annual temperature were $8.18^{\circ} \mathrm{C}, 8.01^{\circ} \mathrm{C}$ and $8.64^{\circ} \mathrm{C}$ respectively. But in $21^{\text {st }}$ century, it became about $9.96^{\circ} \mathrm{C}$. Thus it is found that averagely the global annual temperature has decreased from $18^{\text {th }}$ century to $19^{\text {th }}$ century by $-0.17^{\circ} \mathrm{C}$, from $19^{\text {th }}$ century to $20^{\text {th }}$ century, it is increased by $0.63^{\circ} \mathrm{C}$ but from $20^{\text {th }}$ century to $21^{\text {st }}$ century, it is increased by $1.32^{\circ} \mathrm{C}$. Thus it can be said that the global average annual temperature is increased as a faster rate in $21^{\text {st }}$ century. It is also found that in 2020 the Northern Hemisphere land and ocean surface temperature was the highest within 141 years and it was about $1.28^{\circ} \mathrm{C}$ above of the average temperature. The global average annual temperature from 2020 to 2100 is forecasted and is shown graphically below in Figure 1 .

From the forecasted values in Figure 1, it is can be said that in $22^{\text {nd }}$ century the global average temperature will be increased more rapidly than $21^{\text {st }}$ century.

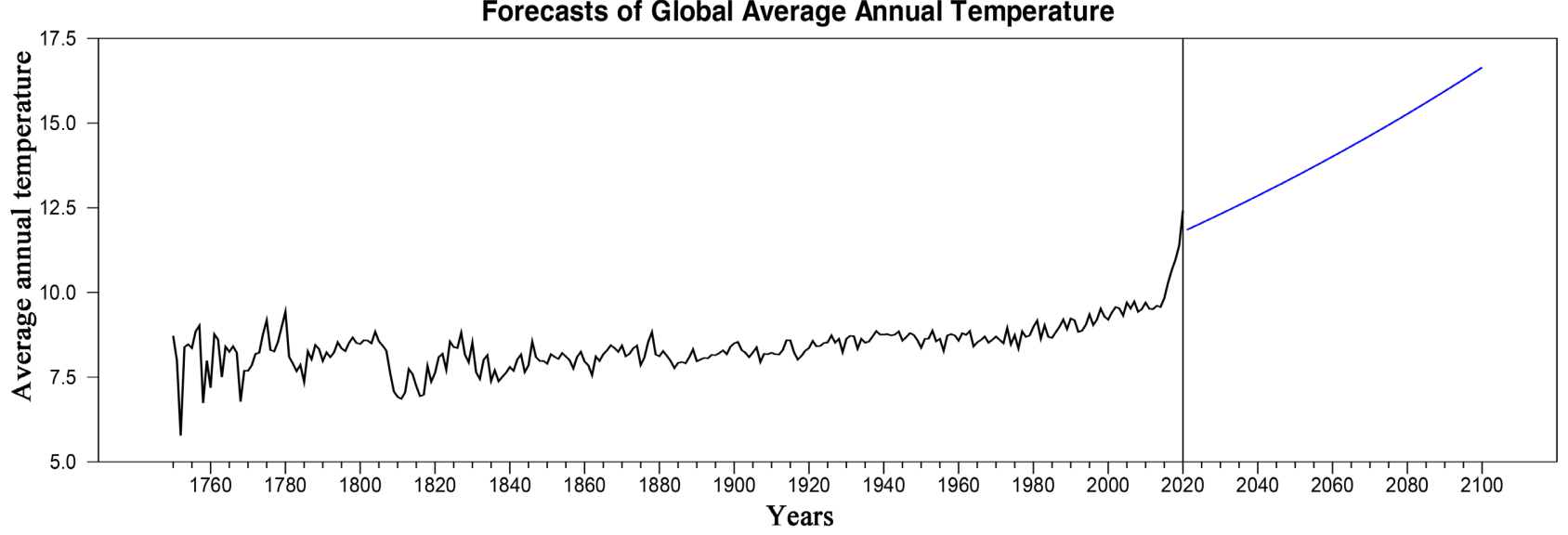

Figure 1. Global average annual temperature with forecasts. 
As a result ice sheets of Antarctic will be melting as a faster rate. At present the world is losing 1.2 trillion tons in each year but in $22^{\text {nd }}$ century the losing rate of ice of the globe will be 2.5 trillion tons in each year and the world will be going to get worse situation. Due to the climate change the global mean sea level (GMSL) is rising rapidly. In $19^{\text {th }}$ and $20^{\text {th }}$ centuries, the average of GMSL were $-145.36 \mathrm{~mm}$ and $-62.47 \mathrm{~mm}$ respectively but in $21^{\text {st }}$ century it became 38.43 $\mathrm{mm}$. Thus it can be said that from $19^{\text {th }}$ century to $20^{\text {th }}$ century the GMSL has risen $82.89 \mathrm{~mm}$ and from $20^{\text {th }}$ century to $21^{\text {st }}$ century it has risen $100.90 \mathrm{~mm}$ averagely. The GMSL are forecasted from 2020 to 2100 and are shown graphically below in Figure 2 .

From the forecasted values in Figure 2, it can be said that in $22^{\text {nd }}$ century the GMSL will be increased at a faster rate. The gradual rising of global mean see level with other events such as tides, surges, waves and flooding, greatly affect the people who are living in coastal areas specially the people who are living in low countries say Belgium, the Netherlands, Luxembourg, and the people who are living in a number of small island states, including the Republic of Maldives, Federated States of Micronesia, Western Samoa, Fiji, Kiribati, Marshall Islands, Sri Lanka, and Mauritius. Since in recent years the GMSL is rising rapidly therefore it caused destructive erosion, wetland flooding, aquifer and agricultural soil contamination with salt, and lost habitat for fish, birds, and plants. The dangerous hurricanes and typhoons are coinciding with higher sea levels and causing powerful storm with heavy rain and destroy everything in their path. It is found that natural disasters are occurring three times more than 50 years ago. The causes of rising GMSL, exposure, vulnerability, impacts and risk related to GMSL rising and extreme sea level hazards and social responses, associated governance challenges and practices and management tools for enabling social choices are shown below with the Figure 3.

Also, the different natural disasters that are caused due to climate change and for rising global mean sea level are highlighted including the affected areas in a Tabular form below in Table 1 .

As a results in each and every year millions of people including animals and

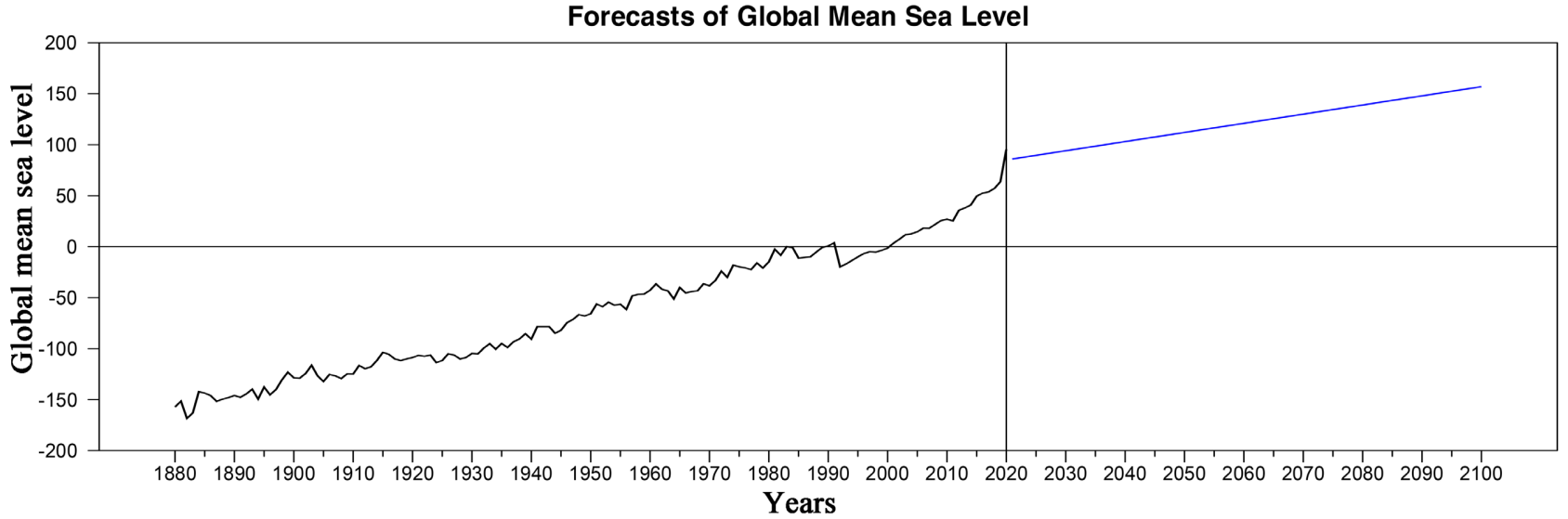

Figure 2. Yearly global mean see level with forecasts. 


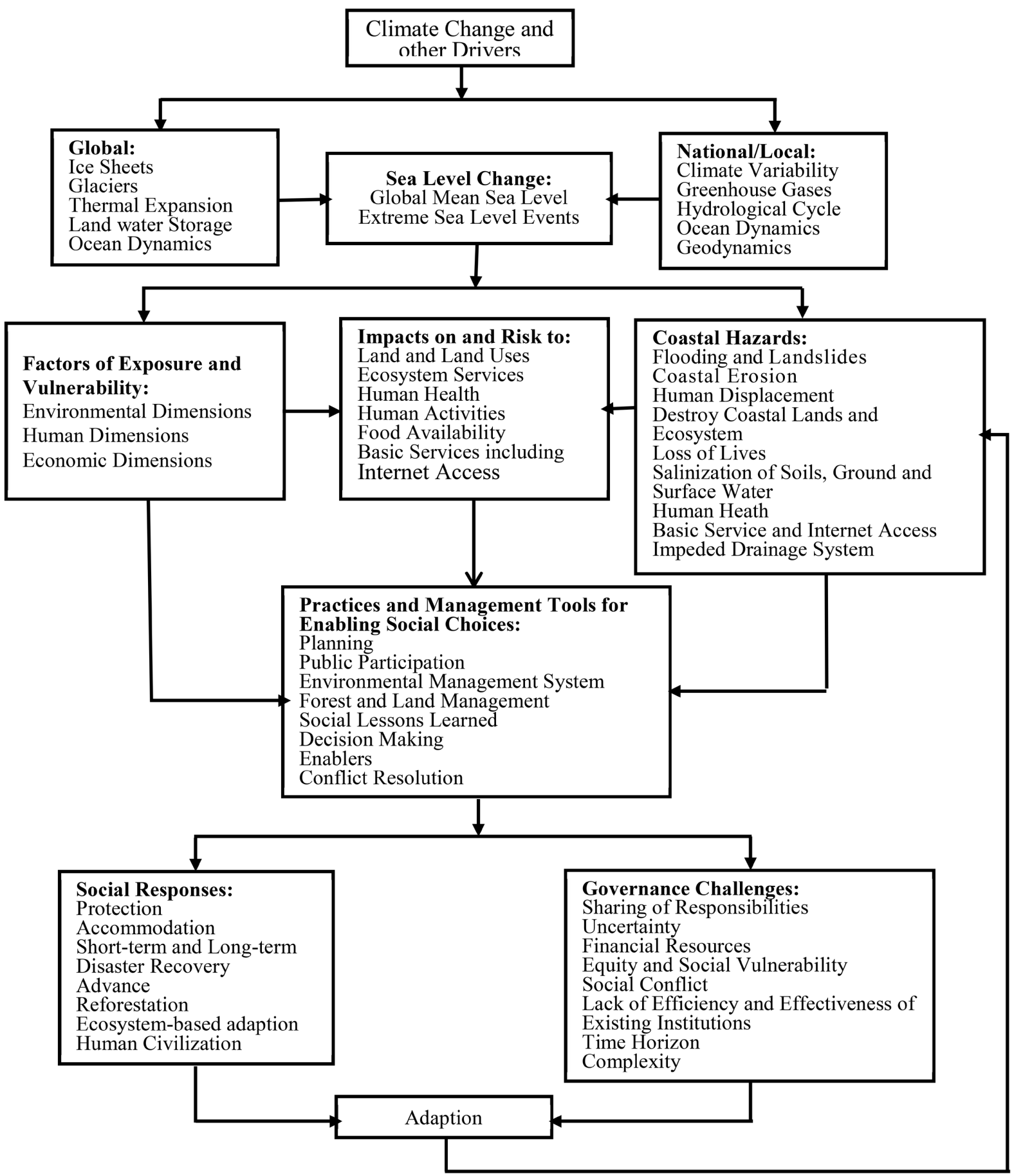

Figure 3. Causes of global mean sea level (GMSL) rising and extreme sea level hazards, exposure, vulnerability, impacts and risk related to GMSL rising, and social responses, associated governance challenges and practices and management tools for enabling social choices.

birds have died, a large number of houses including farm lands, and fish enclosures are destroyed, a large number of people were displaced from low-lying coastal areas to higher ground people, and millions more people are vulnerable from flood risk and other climate change effects. The agricultural productions including livestock, and fisheries are affected in large scale. For the climate change 
Table 1. Different natural disasters.

\begin{tabular}{|c|c|c|}
\hline Affected Country & Name of Disaster & Date \\
\hline Australia & Bushfires & $\begin{array}{l}\text { January: 1, 2, 17, 31, February: 17, 24, } \\
\text { March: 9, 23, 25, 31, April: 4, 10, 13, 21, 22, } \\
24, \\
\text { May: } 7,17, \\
\text { June: } 18,30, \\
\text { July: } 1,6,7,9,15,20,22,23,28, \\
\text { August: } 3,21,23 \text {, September: } 8,11,14,29, \\
\text { October: } 2,5,10,12,27,31 \text {, } \\
\text { November: } 7,19,23 \text {, December: } 1,7 \text {, in } 2020 \\
\text { February: } 1-7,2021\end{array}$ \\
\hline Bangladesh & Floods and Landslides & June 12, 2017 \\
\hline Bangladesh and India & Tropical Cyclone Yaas & May 26, 2021 \\
\hline China & Floods and Landslides & July 17-July 31, 2021 \\
\hline Ethiopia & Floods & April 24, 2020 \\
\hline $\begin{array}{l}\text { East Africa, including Somalia, Kenya, Ethiopia, Sudan } \\
\text { and Eritrea }\end{array}$ & Locust Infestation & October 2019-February 2020 \\
\hline $\begin{array}{l}\text { Cape Verde, Leeward Islands (especially Barbuda, Saint } \\
\text { Barthelemy Anguilla, Saint Martin and the Virgin } \\
\text { Islands), Greater Antilles (Cuba and Puerto Rico), } \\
\text { Turks and Caicos Islands, Jamaica, The Bahamas, } \\
\text { Eastern United States (especially Florida) }\end{array}$ & Hurricane Irma & September 14, 2017 \\
\hline $\begin{array}{l}\text { Windward Islands, Leeward Antilles, Venezuela, } \\
\text { Colombia, Jamaica, Hispaniola, Puerto Rico, Cuba, } \\
\text { Turks and Caicos Islands, The Bahamas, Southeastern } \\
\text { United States, and Atlantic Canada }\end{array}$ & Hurricane Matthew & September 28, 2016 \\
\hline Indonesia & Floods and Landslides & $\begin{array}{l}\text { May 22, } 2020 \\
\text { February 24, May 2, 28. April 5, } 2021\end{array}$ \\
\hline Somalia & Drought & $2015-2021$ \\
\hline $\begin{array}{l}\text { South America including Venezuela, Peru Ecuador } \\
\text { southeastern Brazil, Paraguay, Bolivia, and northern } \\
\text { Argentina. }\end{array}$ & Drought & $2015-2021$ \\
\hline South Sudan & Floods & June 5, 2019 \\
\hline $\begin{array}{l}\text { Southern Africa including Zambia, Democratic } \\
\text { Republic of Congo, Angola, and Namibia }\end{array}$ & Drought & $2018-2021$ \\
\hline Sri-Lanka & Floods and Landslides & June 5, 2021 \\
\hline Zimbabwe, and Malawi & Tropical Cyclone Idai & March 13, 2019 \\
\hline $\begin{array}{l}\text { Taiwan, China, Japan, Philippines, South Korea, North } \\
\text { Korea, and Okinawa }\end{array}$ & Typhoon Morakot & August 2, 2009 \\
\hline Philippines, Vietnam, Thailand, and Laos & Typhoon Vamco & November 9, 2020 \\
\hline Turkey & Wildfires & July 28-August 12, 2021 \\
\hline Greece & Wildfires & July 29-August, 2021 \\
\hline
\end{tabular}


food security at the global, regional, and local level will be affected. Climate change can disrupt food availability, reduce access to food, and affect food quality. The prospect of higher coastal water levels threatens basic services such as Internet access, since much of the underlying communications infrastructure lies in the path of rising seas.

Therefore, it is very much important for the researchers and also for policy makers to know the determinants of rising global mean sea level. A question, therefore arises on our mind whether there exists a long-run relationship between GMSL and climate change. That is why, in this paper the principal purpose has been made to examine empirically the dynamic cointegration and causal relationships between GMSL and its determinants say climate change, carbon dioxide emissions, energy consumption, trade openness and urbanization. Also another purpose has been made to investigate the short-run and long-run effects of climate change, carbon dioxide emissions, energy consumption, trade openness and urbanization on global mean sea level using modern econometric techniques based on the world time series data from 1970-2019 for appropriate policy formulations about our environment. The investigation of the dynamic short-run and long-run causal relationships between the variables involves the following steps. At the first step, the existence of a unit root in each variable is examined using ADF, PP and KPSS unit root tests. If unit root problem presents, then at the second step long run co-integration relationships among the variables are examined using bounds test approach. If a long-run relationship between the variables is found, then at the third step a VEC model is estimated to determine the direction of the causal relationships between the variables using the Granger causality test. At the final step, the appropriate technique is applied to examine the short-run and the long-run impacts of climate change, carbon dioxide emissions, energy consumption, trade openness and urbanization on global mean see level. To test the stability of the model, the cumulative sum (CUSUM) and cumulative sum of squares (CUSUMSQ) tests proposed by Borensztein et al. (1998) are applied. The diagnostic tests for serial correlation, heteroscedasticity and autoregressive conditional heteroscedasticity are applied in the short-run model. Also response functions are estimated in order to find responses of the variables climate change, carbon dioxide emissions, energy consumption, urbanization and trade openness in the variable global mean sea level for the next 10 years. Based on the estimated results appropriate policies can be derived for better environmental quality which can save our nature and lives. The organizational structure of the paper is as follows: Section 2 presents a literature review; Section 3 discusses data sources and some descriptive statistics; Section 4 provides econometric methodology and empirical analyses and finally Section 5 concludes with a summary of the main findings and policy implications.

\section{Literature Review}

The rise in global mean sea level (GMSL) and greenhouse gas emissions are the 
intrinsic measures of global climate change. The global mean sea level is rising extremely due to the thermal expansion of the warming ocean's water and the increase of ocean's mass from melting terrestrial ice sheets. The major sources of greenhouse gas emissions are burning fossil fuels for electricity, heat and transportation. A very few empirical studies have been conducted to show how the global mean sea level rise working as a main driver for climate change see for example: Church et al., (2011, 2013); Frederikse et al., (2020); Horton et al. (2020), Rhein et al., (2013); For the regional and coastal sea level extremes, the global mean sea level rise is working as a major driver see for example: Marcos \& Woodworth (2017); Nerem et al. (2018); and Woodworth et al. (2017). A very few empirical studies have also been conducted in order to find the effects of climate change on millions of human lives, assets and global ecosystems see for example: Anthoff et al. (2010) have found that the costs of sea-level rise increase with greater rise due to growing damage and protection costs, they also found that socio-economic scenarios downscaled to the national level including the four SRES due to rise in global mean sea level. ADB (2013) highlighted that overall, global warming is expected to negative impact on crop productivity (losses in excess of $50 \%$ of yield by 2050 ), fisheries (decreases by $7.5 \%$ by 2100 ), and tourism revenues (reduces $27 \%-34 \%$ by 2100 ) in the pacific. The results of this report suggest net negative impacts of climate change for the Pacific by 2050 in all scenarios regardless of which model is used. The cost of climate change of the Pacific will be $12.7 \%$ of annual GDP by 2100 . This report highlighted that rising sea level has significant impact their coastal cities and communities as well as damage infrastructure and human habitats in the Pacific. This report also introduced increasing temperature as well as changes in rainfall patterns are likewise expected to adversely impact the region's water resources and its agriculture and health sectors; Burke et al. (2015) have found that unmitigated warming is expected to reshape the global economy by reducing average global incomes roughly $23 \%$ by 2100 and widening global income inequality; Dell et al. (2012) have found that higher temperatures substantially reduce economic growth in poor countries, it may reduce growth rates, not just the level of output and it may have wide-ranging effects, reducing agricultural output, industrial output, and political stability, Diaz et al. (2016) have found that the global net present costs through 2100 by a factor of seven to less than $\$ 1.7$ trillion, although this does not include initial transition costs to overcome an under-adapted current state; Ebru et al. (2020) have found that there will be an increase of $48 \%$ of the world's land area, $52 \%$ of the global population and $46 \%$ of global assets at risk of flooding by 2100 . A total of $68 \%$ of the global coastal area flooded will be caused by tide and storm events with $32 \%$ due to projected regional sea level rise; Ericson et al. (2006) have found that 8.7 million people and $28,000 \mathrm{~km}^{2}$ of deltaic area in the sample set of deltas could suffer due to effective sea level rise through 2050; Hallegatte (2012) has concluded that the sizeable impacts of sea level rise on economic growth and welfare are possible, at least at the regional scale, but 
the author could not quantify this effect based on his current knowledge; Nicholls \& Cazenave (2011) have found that the impacts of sea-level rise are potentially large, the application and success of adaptation are large uncertainties that require more assessment and consideration; Ruben and Minsoo (2017) have found that the global GDP will loss $0.3 \%-9.3 \%$ by 2100 ; Vitousek et al. (2017) have highlighted that the gradual sea-level rise can rapidly increase the frequency and severity of coastal flooding. They have also estimated of increased coastal flooding due to sea-level rise have not considered elevated water levels due to waves, and thus underestimate the potential impact; Vousdoukas et al. (2018) have projected a very likely increase of the global average 100-year extreme sea level of $34-76 \mathrm{~cm}$ under a moderate-emission-mitigation-policy scenario and of $58-172 \mathrm{~cm}$ under a business as usual scenario between the year 2000 and 2100 . They have highlighted that the thermal expansion, followed by contributions from ice mass-loss from glaciers, and ice-sheets in Greenland and Antarctica are the main drivers for extreme sea level rise. By the end of this century this applies to most coastlines around the world, implying unprecedented flood risk levels unless timely adaptation measures are taken; Milne et al. (2009) have identified the causes of sea level change. They have highlighted that the significant volume reductions of both the Greenland and West Antarctic ice sheets were largely responsible and that rates of sea-level change during this period may have reached values exceeding $1 \mathrm{~m}$ per century.

According to the knowledge of the author, still now no one has conducted any research to investigate the dynamic cointegration and causality relationships between global mean sea level and its determinants, to find the short-run and long-run impacts of these factors on global mean sea level rise using the modern econometrics techniques and to know what are the responses of the determinants say climate change, carbon dioxide emissions, energy consumption, trade openness and urbanization in the global mean sea level rise for future. Therefore, this study attempts to investigate the dynamic cointegration and causality relationships between global mean sea level and climate change, carbon dioxide emissions, energy consumptions, urbanization and trade openness to fulfill the gap in the literature. Also this study attempts to find the long-run and short-run impacts of these factors on global mean sea level using the modern econometric techniques. Also response functions are estimated in order to find responses of the variables climate change, carbon dioxide emissions, energy consumption, urbanization and trade openness in the variable global mean sea level for the next 10 years.

\section{Data Sources and Some Descriptive Statistics}

This study uses annual time series data from 1970 to 2019 of the world in order to find out the long-run and short-run impacts of climate change, and other selected variables on global mean sea level (GMSL). The variables in the model are climate change (TEM), per capital carbon dioxide emissions $\left(\mathrm{CO}_{2}\right)$, per capita 
energy consumptions (EN), urbanization (UR) and trade openness (OPN). The annual data for global temperature (TEM), and $\mathrm{CO}_{2}$ emissions $\left(\mathrm{CO}_{2}\right)$ (metric tons per capita), and energy consumption (EN) ( $\mathrm{kg}$ of oil equivalent per capita) are used as the proxy variables for climate change, trade openness (OPN) (\% of exports and imports of GDP) is used as the proxy of foreign trade, and the variable urbanization (UR) (\% of urban population of total) is used as a proxy variable of deforestation in the model. The trade openness index measuring the degree of trade liberalization of the word which is measured in US dollars at constant 2010 price. The variables $\mathrm{CO}_{2}, \mathrm{EN}, \mathrm{UR}$ and OPN are downloaded from the World Bank's Development Indicators. The variable TEM is measured in degree celsius $\left({ }^{\circ} \mathrm{C}\right)$ and the global mean sea level (GMSL) is measured in millimeter $(\mathrm{mm})$ which are downloaded from NOAA (National Centers for Global Information), NASA, and Berkeley Earth. The descriptive statistics mean, median, standard deviation (Std. Dev.), coefficient of variation (CV), skewness, and Kurtosis of these variables are recorded below in Table 2.

From the reported values in Table 3, it is found that the variability is highest for the variable global mean sea level followed by trade openness, urbanization, energy consumption, temperature and carbon dioxide emissions. The results also support that the variables GMSL, TEM, EN, UR and OPN are positively skewed while the variable $\mathrm{CO}_{2}$ is negatively skewed. The results also support that the curve of the variable TEM is leptokurtic and the curves of the variables GMSL, $\mathrm{CO}_{2}$, EN, UR and OPN are platykurtic.

\section{Econometric Methodology and Empirical Analyses}

To investigate the short-run and long-run effects of the variables TEM, $\mathrm{CO}_{2}, \mathrm{EN}$, UR and OPN on GMSL this section covers the following econometric methodologies: unit root tests, cointegration test, Granger causality analysis, estimation of long-run and short-run equations. Also this section covers impulse response analysis including the estimated results of these econometric methodologies and

Table 2. Some descriptive statistics.

\begin{tabular}{ccccccc}
\hline $\begin{array}{c}\text { Descriptive } \\
\text { Statistics }\end{array}$ & GMSL & TEM & $\mathrm{CO}_{2}$ & EN & UR & OPN \\
\hline Mean & 3.8534 & 9.2646 & 4.2906 & 1625.867 & 45.1802 & 45.1029 \\
Median & -1.9100 & 9.2000 & 4.3011 & 1622.617 & 44.6540 & 42.3762 \\
SD & 25.1257 & 0.6089 & 0.2652 & 203.9125 & 5.8426 & 10.4874 \\
CV & 652.0397 & 6.5758 & 6.1810 & 12.5418 & 12.9318 & 23.2521 \\
Skewness & 0.7196 & 1.4011 & -0.1434 & 0.3206 & 0.2086 & 0.1310 \\
Kurtosis & 2.7216 & 5.5987 & 1.9742 & 1.8153 & 1.8247 & 1.7104 \\
Max & 63.7600 & 11.4000 & 4.7537 & 2001.888 & 55.7147 & 60.7886 \\
Min & -38.3000 & 8.3500 & 3.8370 & 1337.612 & 36.5634 & 27.3008 \\
Range & 102.0500 & 3.0500 & 0.9167 & 664.276 & 19.1513 & 33.4878 \\
\hline
\end{tabular}


Table 3. The Augmented Dickey-Fuller (ADF), Phillips-Perron (PP) and Kwiatkowski-Phillips-SchmidtShin (KPSS) Tests Results.

\begin{tabular}{|c|c|c|c|c|c|c|c|c|}
\hline \multirow[t]{2}{*}{ Variable } & \multicolumn{3}{|c|}{ ADF Test [Level Form] } & \multicolumn{3}{|c|}{ PP Test [Level Form] } & \multicolumn{2}{|c|}{$\begin{array}{l}\text { KPSS Test[Level } \\
\text { Form] }\end{array}$} \\
\hline & Case 1 & Case 2 & Case 3 & Case 1 & Case 2 & Case 3 & Case 1 & Case 2 \\
\hline GMSL & $\begin{array}{l}-1.4275 \\
(0.8403)\end{array}$ & $\begin{array}{c}0.1416 \\
(0.9658)\end{array}$ & $\begin{array}{c}0.3987 \\
(0.7949)\end{array}$ & $\begin{array}{l}-1.2393 \\
(0.8909)\end{array}$ & $\begin{array}{c}0.3404 \\
(0.9782)\end{array}$ & $\begin{array}{c}0.3712 \\
(0.7878)\end{array}$ & $\begin{array}{c}0.4422 \\
(0.1460)\end{array}$ & $\begin{array}{c}0.8512 \\
(0.4630)\end{array}$ \\
\hline TEM & $\begin{array}{l}-1.7785 \\
(0.6999)\end{array}$ & $\begin{array}{c}1.8292 \\
(0.9997)\end{array}$ & $\begin{array}{c}1.4609 \\
(0.9625)\end{array}$ & $\begin{array}{l}-1.4793 \\
(0.8234)\end{array}$ & $\begin{array}{c}1.5681 \\
(0.9993)\end{array}$ & $\begin{array}{c}1.4609 \\
(0.9625)\end{array}$ & $\begin{array}{c}0.2153 \\
(0.1460)\end{array}$ & $\begin{array}{c}0.8730 \\
(0.4630)\end{array}$ \\
\hline $\mathrm{CO}_{2}$ & $\begin{array}{l}-1.3502 \\
(0.8631)\end{array}$ & $\begin{array}{l}-1.2978 \\
(0.6235)\end{array}$ & $\begin{array}{c}0.6605 \\
(0.8554)\end{array}$ & $\begin{array}{l}-1.6834 \\
(0.7435)\end{array}$ & $\begin{array}{l}-1.6184 \\
(0.4658)\end{array}$ & $\begin{array}{c}0.5328 \\
(0.8276)\end{array}$ & $\begin{array}{c}0.2213 \\
(0.1460)\end{array}$ & $\begin{array}{c}0.5693 \\
(0.4630)\end{array}$ \\
\hline $\mathrm{EN}$ & $\begin{array}{c}-2.51104 \\
(0.3218)\end{array}$ & $\begin{array}{c}0.1535 \\
(0.9667)\end{array}$ & $\begin{array}{c}2.4778 \\
(0.9963)\end{array}$ & $\begin{array}{c}-2.5110 \\
(0.318)\end{array}$ & $\begin{array}{c}0.2502 \\
(0.9731)\end{array}$ & $\begin{array}{c}2.6749 \\
(0.9978)\end{array}$ & $\begin{array}{c}0.1757 \\
(0.1460)\end{array}$ & $\begin{array}{c}1.2876 \\
(0.4630)\end{array}$ \\
\hline UR & $\begin{array}{l}-1.4995 \\
(0.8158)\end{array}$ & $\begin{array}{c}1.2841 \\
(0.9982)\end{array}$ & $\begin{array}{c}2.8421 \\
(0.9986)\end{array}$ & $\begin{array}{l}-2.2547 \\
(0.4498)\end{array}$ & $\begin{array}{l}4.7539 \\
(1.000)\end{array}$ & $\begin{array}{r}26.3885 \\
(1.000)\end{array}$ & $\begin{array}{c}0.2376 \\
(0.1460)\end{array}$ & $\begin{array}{c}0.9362 \\
(0.4630)\end{array}$ \\
\hline OPN & $\begin{array}{l}-2.8163 \\
(0.1986)\end{array}$ & $\begin{array}{l}-1.0104 \\
(0.7425)\end{array}$ & $\begin{array}{c}1.8605 \\
(0.9837)\end{array}$ & $\begin{array}{l}-2.8164 \\
(0.1986)\end{array}$ & $\begin{array}{l}-0.9206 \\
(0.7734)\end{array}$ & $\begin{array}{c}2.6469 \\
(0.9976)\end{array}$ & $\begin{array}{c}0.2015 \\
(0.1460)\end{array}$ & $\begin{array}{c}2.4703 \\
(0.4630)\end{array}$ \\
\hline & \multicolumn{3}{|c|}{ ADF Test [Differenced Form] } & \multicolumn{3}{|c|}{ PP Test [Differenced Form] } & \multicolumn{2}{|c|}{$\begin{array}{c}\text { KPSS Test } \\
\text { [Differenced Form] }\end{array}$} \\
\hline GMSL & $\begin{array}{c}-8.2783^{\star *} \\
(0.0000)\end{array}$ & $\begin{array}{l}-8.204^{\star *} \\
(0.0000)\end{array}$ & $\begin{array}{l}-7.249^{* *} \\
(0.0000)\end{array}$ & $\begin{array}{l}-8.365^{\star *} \\
(0.0000)\end{array}$ & $\begin{array}{l}-8.204^{\star *} \\
(0.0000)\end{array}$ & $\begin{array}{l}-7.244^{\star *} \\
(0.0000)\end{array}$ & $\begin{array}{l}0.0943^{\star *} \\
(0.1460)\end{array}$ & $\begin{array}{l}0.1487^{\star *} \\
(0.4630)\end{array}$ \\
\hline TEM & $\begin{array}{c}-10.206^{* *} \\
(0.0000)\end{array}$ & $\begin{array}{l}-9.710^{\star *} \\
(0.0000)\end{array}$ & $\begin{array}{l}-9.209^{* *} \\
(0.0000)\end{array}$ & $\begin{array}{l}-10.26^{\star *} \\
(0.0000)\end{array}$ & $\begin{array}{l}-9.549^{* *} \\
(0.0000)\end{array}$ & $\begin{array}{l}-9.001^{\star *} \\
(0.0000)\end{array}$ & $\begin{array}{l}0.1135^{\star} \\
(0.1460)\end{array}$ & $\begin{array}{l}0.2351^{\star *} \\
(0.4630)\end{array}$ \\
\hline $\mathrm{CO}_{2}$ & $\begin{array}{c}-5.4083^{\star \star} \\
(0.0003)\end{array}$ & $\begin{array}{l}-5.464^{\star *} \\
(0.0000)\end{array}$ & $\begin{array}{l}-5.491^{\star *} \\
(0.0000)\end{array}$ & $\begin{array}{l}-5.408^{\star *} \\
(0.0003)\end{array}$ & $\begin{array}{l}-5.441^{\star *} \\
(0.0000)\end{array}$ & $\begin{array}{l}-5.466^{\star *} \\
(0.0000)\end{array}$ & $\begin{array}{l}0.1022^{\star *} \\
(0.1460)\end{array}$ & $\begin{array}{c}0.1033 \\
(0.4630)\end{array}$ \\
\hline $\mathrm{EN}$ & $\begin{array}{l}-6.8411^{\star} \\
(0.0001)\end{array}$ & $\begin{array}{l}-6.880^{\star *} \\
(0.0001)\end{array}$ & $\begin{array}{l}-6.099^{* *} \\
(0.0001)\end{array}$ & $\begin{array}{l}-6.852^{\star *} \\
(0.0001)\end{array}$ & $\begin{array}{l}-6.891^{\star *} \\
(0.0001)\end{array}$ & $\begin{array}{l}-6.108^{\star *} \\
(0.0001)\end{array}$ & $\begin{array}{l}0.0389^{* *} \\
(0.1460)\end{array}$ & $\begin{array}{l}0.1190^{*} \\
(0.4630)\end{array}$ \\
\hline UR & $\begin{array}{l}-2.5696 \\
(0.2954)\end{array}$ & $\begin{array}{l}-2.3469 \\
(0.1621)\end{array}$ & $\begin{array}{c}0.9631 \\
(0.9087)\end{array}$ & $\begin{array}{l}-2.0183 \\
(0.5767)\end{array}$ & $\begin{array}{l}-2.4525 \\
(0.1334)\end{array}$ & $\begin{array}{c}0.9632 \\
(0.9087)\end{array}$ & $\begin{array}{l}0.0834^{\star *} \\
(0.1460)\end{array}$ & $\begin{array}{l}0.7316^{\star} \\
(0.7390)\end{array}$ \\
\hline OPN & $\begin{array}{c}-7.7588^{\star \star} \\
(0.0001)\end{array}$ & $\begin{array}{l}-7.817^{\star *} \\
(0.0001)\end{array}$ & $\begin{array}{l}-7.123^{\star *} \\
(0.0001)\end{array}$ & $\begin{array}{l}-8.235^{\star *} \\
(0.0001)\end{array}$ & $\begin{array}{l}-8.237^{\star *} \\
(0.0001)\end{array}$ & $\begin{array}{l}-7.123^{\star *} \\
(0.0001)\end{array}$ & $\begin{array}{l}0.0959^{* *} \\
(0.1460)\end{array}$ & $\begin{array}{l}0.0982^{\star *} \\
(0.4630)\end{array}$ \\
\hline
\end{tabular}

Case 1: Constant and trend terms are included in the model; Case 2: Only Constant term is included in the mode, Case 3: No Constant and trend terms are included in the model. The reported values in the parentheses are the probabilities. ${ }^{* *}$ : indicates significant at $10 \%$ or any significance level, ${ }^{*}$ : indicates significant at $5 \%$ level.

critical explanation on the estimated results.

The long-run effect of the factors on GMSL is examined by considering the following model:

$$
\mathrm{GMSL}_{t}=\beta_{0}+\beta_{1} \mathrm{TEM}_{t}+\beta_{2} \mathrm{CO}_{2}+\beta_{3} \mathrm{EN}_{t}+\beta_{4} \mathrm{UR}_{t}+\beta_{5} \mathrm{OPN}_{t}+\varepsilon_{t}
$$

Here, $\beta_{0}$ is a constant. $\beta_{1}, \beta_{2}, \beta_{3}, \beta_{4}$, and $\beta_{5}$ denote the long-run effects of the variables TEM, $\mathrm{CO}_{2}$, EN, UR and OPN on GMSL. The subscript $t$ denotes the time period from 1970-2019. $\varepsilon_{t}$ represents the random error term. 


\subsection{Unit Root Test}

Application of the usual techniques of regression analysis can result in highly misleading conclusion when variables contains stochastic trend (Stock and Watson (1988), Granger and Newbold (1974). In particular if the dependent variable and at least one independent variable contain stochastic trend, and if they are not co-integrated, the regression results are spurious (Phillips, 1987; Granger and Newbold, 1974). To identify the correct specification of the model, an investigation of the presence of stochastic trend in the variables is needed. The Augmented Dickey-Fuller (ADF), Phillips-Perron (PP) and Kwiatkowski-PhillipsSchmidt-Shin (KPSS) tests are applied in order to check whether each variable contains stochastic trend. The lagged differences of the estimated equations are selected by using AIC, SBIC and HQC criterion. The ADF, PP and KPSS tests results at different cases are given below in Table 3 .

In differenced form the trend value will be reduced from the equation but here we estimated the equation for both with and without trend value in the differenced form equation. From the test results it can be concluded that all the variables are integrated of order 1 . The presence of unit root problems in each variable indicates the existence of the long-run cointegration relationships among the variables. Therefore it is common to test for detecting the long-run cointegaration relationships among the variables.

\subsection{Bounds Test Approach for Cointegration}

The bounds test approach for cointegration, known as the autoregressive-distributed lag (ARDL) of Pesaran et al. (2001), has become most popular amongst researchers. The bounds test approach has certain econometric advantages in comparison to other single equation cointegration procedure. They are as follows; 1 ) endogeneity problems and inability to test hypotheses on the estimated coefficients in the long-run associated with the Engle-Granger method are avoided; 2) the long-run and short-run parameters of the model in question are estimated simultaneously; 3 ) the bounds test approach for testing the existence of long-run relationship between the variables in levels is applicable irrespective of whether the underlying time series variables are purely $\mathrm{I}(0), \mathrm{I}(1)$ or fractionally integrated; 4) the small sample properties of the bounds testing approach are far superior to that of multivariate analysis. In this paper to implement the bounds test for cointegration, the following unrestricted regression equations have been formulated:

$$
\begin{aligned}
\Delta \mathrm{GMSL}_{t}= & \alpha_{0}+\sum_{i=1}^{p} \alpha_{1 i} \Delta \mathrm{GMSL}_{t-i}+\sum_{i=0}^{p} \alpha_{2 i} \Delta \mathrm{TEM}_{t-i}+\sum_{i=0}^{p} \alpha_{3 i} \Delta \mathrm{CO}_{2_{t-i}} \\
& +\sum_{i=0}^{p} \alpha_{4 i} \Delta \mathrm{EN}_{t-i}+\sum_{i=0}^{p} \alpha_{5 i} \Delta \mathrm{UR}_{t-i}+\sum_{i=0}^{p} \alpha_{6 i} \Delta \mathrm{OPN}_{t-i} \\
& +\alpha_{7} \mathrm{GMSL}_{t-1}+\alpha_{8} \mathrm{TEM}_{t-1}+\alpha_{9} \mathrm{CO}_{2_{t-1}}+\alpha_{10} \mathrm{EN}_{t-1} \\
& +\alpha_{11} \mathrm{UR}_{t-1}+\alpha_{12} \mathrm{OPN}_{t-1}+\varepsilon_{1 t}
\end{aligned}
$$




$$
\begin{aligned}
& \Delta \mathrm{TEM}_{t}=\beta_{0}+\sum_{i=0}^{p} \beta_{1 i} \Delta \mathrm{GMSL}_{t-i}+\sum_{i=1}^{p} \beta_{2 i} \Delta \mathrm{TEM}_{t-i}+\sum_{i=0}^{p} \beta_{3 i} \Delta \mathrm{CO}_{2_{t-i}} \\
& +\sum_{i=0}^{p} \beta_{4 i} \Delta \mathrm{EN}_{t-i}+\sum_{i=0}^{p} \beta_{5 i} \Delta \mathrm{UR}_{t-i}+\sum_{i=0}^{p} \beta_{6 i} \Delta \mathrm{OPN}_{t-i} \\
& +\beta_{7} \mathrm{GMSL}_{t-1}+\beta_{8} \mathrm{TEM}_{t-1}+\beta_{9} \mathrm{CO}_{2_{t-1}}+\beta_{10} \mathrm{EN}_{t-1} \\
& +\beta_{11} \mathrm{UR}_{t-1}+\beta_{12} \mathrm{OPN}_{t-1}+\varepsilon_{2 t} \\
& \Delta \mathrm{CO}_{2_{t}}=\delta_{0}+\sum_{i=0}^{p} \delta_{1 i} \Delta \mathrm{GMSL}_{t-i}+\sum_{i=0}^{p} \delta_{2 i} \Delta \mathrm{TEM}_{t-i}+\sum_{i=1}^{p} \delta_{3 i} \Delta \mathrm{CO}_{2_{t-i}} \\
& +\sum_{i=0}^{p} \delta_{4 i} \Delta \mathrm{EN}_{t-i}+\sum_{i=0}^{p} \delta_{5 i} \Delta \mathrm{UR}_{t-i}+\sum_{i=0}^{p} \delta_{6 i} \Delta \mathrm{OPN}_{t-i} \\
& +\delta_{7} \mathrm{GMSL}_{t-1}+\delta_{8} \mathrm{TEM}_{t-1}+\delta_{9} \mathrm{CO}_{2 t-1}+\delta_{10} \mathrm{EN}_{t-1} \\
& +\delta_{11} \mathrm{UR}_{t-1}+\delta_{12} \mathrm{OPN}_{t-1}+\varepsilon_{3 t} \\
& \Delta \mathrm{EN}_{t}=\theta_{0}+\sum_{i=0}^{p} \theta_{1 i} \Delta \mathrm{GMSL}_{t-i}+\sum_{i=0}^{p} \theta_{2 i} \Delta \mathrm{TEM}_{t-i}+\sum_{i=0}^{p} \theta_{3 i} \Delta \mathrm{CO}_{2_{t-i}} \\
& +\sum_{i=1}^{p} \theta_{4 i} \Delta \mathrm{EN}_{t-i}+\sum_{i=0}^{p} \theta_{5 i} \Delta \mathrm{UR}_{t-i}+\sum_{i=0}^{p} \theta_{6 i} \Delta \mathrm{OPN}_{t-i} \\
& +\theta_{7} \mathrm{GMSL}_{t-1}+\theta_{8} \mathrm{TEM}_{t-1}+\theta_{9} \mathrm{CO}_{2_{t-1}}+\theta_{10} \mathrm{EN}_{t-1} \\
& +\theta_{11} \mathrm{UR}_{t-1}+\theta_{12} \mathrm{OPN}_{t-1}+\varepsilon_{4 t} \\
& \Delta \mathrm{UR}_{t}=\gamma_{0}+\sum_{i=0}^{p} \gamma_{1 i} \Delta \mathrm{GMSL}_{t-i}+\sum_{i=0}^{p} \gamma_{2 i} \Delta \mathrm{TEM}_{t-i}+\sum_{i=0}^{p} \gamma_{3 i} \Delta \mathrm{CO}_{2_{t-i}} \\
& +\sum_{i=0}^{p} \gamma_{4 i} \Delta \mathrm{EN}_{t-i}+\sum_{i=1}^{p} \gamma_{5 i} \Delta \mathrm{UR}_{t-i}+\sum_{i=0}^{p} \gamma_{6 i} \Delta \mathrm{OPN}_{t-i} \\
& +\gamma_{7} \mathrm{GMSL}_{t-1}+\gamma_{8} \mathrm{TEM}_{t-1}+\gamma_{9} \mathrm{CO}_{2_{t-1}}+\gamma_{10} \mathrm{EN}_{t-1} \\
& +\gamma_{11} \mathrm{UR}_{t-1}+\gamma_{12} \mathrm{OPN}_{t-1}+\varepsilon_{5 t} \\
& \Delta \mathrm{OPN}_{t}=\varphi_{0}+\sum_{i=0}^{p} \varphi_{1 i} \Delta \mathrm{GMSL}_{t-i}+\sum_{i=0}^{p} \varphi_{2 i} \Delta \mathrm{TEM}_{t-i}+\sum_{i=0}^{p} \varphi_{3 i} \Delta \mathrm{CO}_{2_{t-i}} \\
& +\sum_{i=0}^{p} \varphi_{4 i} \Delta \mathrm{EN}_{t-i}+\sum_{i=0}^{p} \varphi_{5 i} \Delta \mathrm{UR}_{t-i}+\sum_{i=1}^{p} \varphi_{6 i} \Delta \mathrm{OPN}_{t-i} \\
& +\varphi_{7} \mathrm{GMSL}_{t-1}+\varphi_{8} \mathrm{TEM}_{t-1}+\varphi_{9} \mathrm{CO}_{2_{t-1}}+\varphi_{10} \mathrm{EN}_{t-1} \\
& +\varphi_{11} \mathrm{UR}_{t-1}+\varphi_{12} \mathrm{OPN}_{t-1}+\varepsilon_{6 t}
\end{aligned}
$$

According to Pesaran et al. (2001), the joint F-test of the lagged level variables in Equations (2)-(7) are used to test the presence of long-run equilibrium relationship. For instance in Equation (2) the test for cointegration is carried out by testing the null hypothesis of no conintegration is defined by $\mathrm{H}_{0}: \alpha_{7}=\alpha_{8}=\cdots=\alpha_{12}=0$, using the F-test. The variables are said to be cointegrated if the null hypothesis of no cointegration is rejected; otherwise the variables are not cointegrated. Similarly, procedures can also be carried out for testing the long-run equilibrium relationships for Equations (3)-(7).

The asymptotic distribution of the F-statistic is non-standard under null hypothesis and it was originally derived and tabulated by Pesaran et al. (2001) but later modified by Narayan (2005) to accommodate small sample sizes. Two sets of critical values are provided; one which is appropriate where all the series are 
$\mathrm{I}(0)$ and the other is appropriate where all the variables are I(1). According to Pesaran et al. (2001), if the calculated F-statistic falls above the upper critical value, a conclusive inference can be made regarding cointegration without knowing whether the series are $\mathrm{I}(0)$ or $\mathrm{I}(1)$. In this case the variables are said to be cointegrated indicates existence of long-run relationship among the variables. Alternatively if the calculated F-statistic falls below the lower critical value the null hypothesis of no cointegration will not be rejected regardless whether the series are $\mathrm{I}(0)$ or $\mathrm{I}(1)$. In contrast the inference is inconclusive if the calculated F-statistic falls within lower and upper critical values unless we know whether the series are $\mathrm{I}(0)$ or (1). The estimated results are given below in Table 4.

From the estimated results it can be concluded that there exits only one cointegration relationship refers to the situation where GMSL is the dependent variable.

\subsection{Granger Causality Analysis: VEC Model}

The cointegration relationship indicates the existence of causal relationship but it does not indicate the direction of causal relationship between variables. Therefore it is common to test for detecting the causal relationship between variables using the Engle and Granger test procedure. Since all the variables are I(1) and cointegrated, thus the Granger causality test is applied to $\mathrm{I}(0)$ data with an error correction term. The inclusion of an additional variable to the VAR system such as the error correction term (ECM) would help us to capture the long-run relationship. The augmented form of the Granger causality test involving the error correction term is formulated in a multivariate pth order vector error correction model given as below:

$$
\left[\begin{array}{c}
\Delta \mathrm{GMSL}_{t} \\
\Delta \mathrm{TEM}_{t} \\
\Delta \mathrm{CO}_{2_{t}} \\
\Delta \mathrm{EN}_{t} \\
\Delta \mathrm{UR}_{t} \\
\Delta \mathrm{OPN}_{t}
\end{array}\right]=\left[\begin{array}{c}
C_{1} \\
C_{2} \\
C_{3} \\
C_{4} \\
C_{5} \\
C_{6}
\end{array}\right]+\sum_{i=1}^{p}\left[\begin{array}{llllll}
\beta_{11 i} & \beta_{12 i} & \beta_{13 i} & \beta_{14 i} & \beta_{15 i} & \beta_{16 i} \\
\beta_{21 i} & \beta_{22 i} & \beta_{23 i} & \beta_{24 i} & \beta_{25 i} & \beta_{26 i} \\
\beta_{31 i} & \beta_{32 i} & \beta_{33 i} & \beta_{34 i} & \beta_{35 i} & \beta_{36 i} \\
\beta_{41 i} & \beta_{42 i} & \beta_{43 i} & \beta_{44 i} & \beta_{45 i} & \beta_{46 i} \\
\beta_{51 i} & \beta_{52 i} & \beta_{53 i} & \beta_{54 i} & \beta_{55 i} & \beta_{56 i} \\
\beta_{61 i} & \beta_{62 i} & \beta_{63 i} & \beta_{64 i} & \beta_{65 i} & \beta_{66 i}
\end{array}\right]\left[\begin{array}{c}
\Delta \mathrm{GMSL}_{t} \\
\Delta \mathrm{TEM}_{t} \\
\Delta \mathrm{CO}_{2_{t}} \\
\Delta \mathrm{EN}_{t} \\
\Delta \mathrm{UR}_{t} \\
\Delta \mathrm{OPN}_{t}
\end{array}\right]+\left[\begin{array}{c}
\lambda_{1} \\
\lambda_{2} \\
\lambda_{3} \\
\lambda_{4} \\
\lambda_{5} \\
\lambda_{6}
\end{array}\right] \mathrm{ECM}_{t-1}+\left[\begin{array}{c}
\varepsilon_{1 t} \\
\varepsilon_{2 t} \\
\varepsilon_{3 t} \\
\varepsilon_{4 t} \\
\varepsilon_{5 t} \\
\varepsilon_{6 t}
\end{array}\right]
$$

Table 4. The results of F-Test for cointegration relationship.

\begin{tabular}{ccccc}
\hline Functional Forms & F-test Value & Lags & AIC & SBIC \\
\hline$f\left(\mathrm{GMSL} \mid \mathrm{TEM}, \mathrm{CO}_{2}, \mathrm{EN}, \mathrm{UR}, \mathrm{OPN}\right)$ & $4.6140^{*}$ & 1 & 3.3285 & 3.8353 \\
$f\left(\mathrm{TEM} \mid \mathrm{GMSL}, \mathrm{CO}_{2}, \mathrm{EN}, \mathrm{UR}, \mathrm{OPN}\right)$ & 2.5178 & 1 & -2.7063 & -2.1995 \\
$f\left(\mathrm{CO}_{2} \mid \mathrm{GMSL}, \mathrm{TEM}, \mathrm{EN}, \mathrm{UR}, \mathrm{OPN}\right)$ & 0.6994 & 1 & -4.5106 & -4.0038 \\
$f\left(\mathrm{EN} \mid \mathrm{GMSL}, \mathrm{TEM}, \mathrm{CO}_{2}, \mathrm{UR}, \mathrm{OPN}\right)$ & 1.5037 & 1 & 7.3742 & 7.3542 \\
$f\left(\mathrm{UR} \mid \mathrm{GMSL}, \mathrm{TEM}, \mathrm{CO}_{2}, \mathrm{EN}, \mathrm{OPN}\right)$ & 0.7590 & 1 & -7.2629 & -6.7561 \\
$f\left(\mathrm{OPN} \mid \mathrm{GMSL}, \mathrm{TEM}, \mathrm{CO}_{2}, \mathrm{EN}, \mathrm{OPN}\right)$ & 3.0559 & 1 & 1.4618 & 1.9686 \\
\hline
\end{tabular}

*: indicates significant at $5 \%$ level, The critical value ranges of F-statistic are $4.614-5.966$, $3.272-4.306$ and $2.676-3.586$ at $1 \%, 5 \%$ and $10 \%$ level of significance respectively. See Narayan (2005). 
where, $t=p+1, p+3, \cdots, T$;.The $C$ s, $\beta$ 's and $\lambda$ 's are the parameters to be estimated. $E \mathrm{CM}_{t-1}$ represents the one period lagged error-term derived from the cointegration equation and the $\varepsilon$ 's are serially independent with mean zero and finite covariance matrix. In the VAR structure of the Equation (8), all the variables are treated as endogenous variables. The Granger $\mathrm{F}$ test is applied here to examine the direction of any causal relationship between the variables. The temperature does not Granger cause global mean sea level in the short run, if and only if all the coefficients $\beta_{12 i}$ 's $\forall i$ are not significantly different from zero in Equation (8). Similarly the global mean sea level does not Granger cause temperature in the short run if and only if all the coefficients $\beta_{21 i}$ 's $\forall i$ are not significantly different from zero in the Equation (8). There are referred to as the short-run Granger causality test. The coefficients on the ECM represent how fast deviation from the long-run equilibrium are eliminated in the short-run. Another channel of causality can be studied by testing the significance of ECM's. This test is referred to as the long run causality test. The short-run and long-run Granger causality results are reported below in Table 5 .

The findings in Table 5, indicates that short-run unidirectional causalities are running from carbon dioxide emissions and energy consumption to global mean sea level, from energy consumption and trade openness to carbon dioxide emissions and from trade openness to energy consumption It has been found that the error correction term is statistically significant at any significance level when global mean sea level is treated as the endogenous variables indicating that there exists a long-run relationship among the variables in the form of Equation (1) which is also confirmed by the results of the bounds test approach for cointegration.

\subsection{Short-Run and Long-Run Effects}

Since, it is found that there exists a cointegration relationship when the global

Table 5. The Granger F-Test Results.

\begin{tabular}{cccccccc}
\hline & $\Delta \mathrm{GMSL}$ & $\Delta \mathrm{TEM}$ & $\Delta \mathrm{CO}_{2}$ & $\Delta \mathrm{EN}$ & $\Delta \mathrm{UR}$ & $\Delta \mathrm{OPN}$ & $\mathrm{ECM}$ \\
\hline \multirow{2}{*}{$\Delta \mathrm{GMSL}$} & & 0.2833 & $3.6979^{\star *}$ & $4.3837^{\star}$ & 0.0026 & 0.2559 & $-4.4041^{\star}$ \\
& & $(0.5975)$ & $(0.0616)$ & $(0.0204)$ & $(0.9596)$ & $(0.6157)$ & 0.0001 \\
$\Delta \mathrm{TEM}$ & 0.0251 & & 0.1148 & 0.3485 & 0.6059 & 0.3905 & -0.0514 \\
& $(0.8749)$ & & $(0.7365)$ & $(0.5582)$ & $(0.4409)$ & $(0.5356)$ & $(0.9593)$ \\
& 0.0023 & 0.1032 & & $9.8347^{\star}$ & 0.0275 & $7.6767^{\star}$ & -0.4429 \\
$\Delta \mathrm{CO}_{2}$ & $(0.9620)$ & $(0.7497)$ & & $(0.0004)$ & $(0.8691)$ & $(0.0084)$ & $(0.6603)$ \\
& 1.6989 & 1.3356 & 0.4884 & & 0.1850 & $8.7065^{\star}$ & -1.2443 \\
$\Delta \mathrm{EN}$ & $(0.1999)$ & $(0.2547)$ & $(0.4886)$ & & $(0.6693)$ & $(0.0053)$ & $(0.2206)$ \\
& 0.0816 & 0.0816 & 1.3150 & 0.2579 & & 1.4544 & -0.5134 \\
$\Delta \mathrm{UR}$ & 0.7766 & 0.7766 & 0.2583 & 0.61436 & & $(0.2349)$ & $(0.6105)$ \\
& 0.0203 & 1.5925 & 1.0054 & 0.3451 & 0.4895 & & -0.4269 \\
$\Delta \mathrm{OPN}$ & $(0.8875)$ & $(0.2142)$ & $(0.3220)$ & $(0.5602)$ & $(0.4882)$ & & $(0.6718)$ \\
\hline
\end{tabular}

The figures in the parenthesis are the p-values. ${ }^{*},{ }^{*}$ indicate test statistics that are significant at $5 \%$ and $10 \%$ level, respectively. 
mean sea level is the dependent variable thus the following $\operatorname{ARDL}(m, p, q, r, s$, $w)$ model is estimated for long-run association among the variables:

$$
\begin{aligned}
\mathrm{GMSL}_{t}= & \delta_{0}+\sum_{i=1}^{m} \delta_{1 i} \mathrm{GMSL}_{t-i}+\sum_{i=0}^{p} \delta_{2 i} \mathrm{TEM}_{t-i}+\sum_{i=0}^{q} \delta_{3 i} \mathrm{CO}_{2 t-i} \\
& +\sum_{i=0}^{r} \delta_{4 i} \mathrm{EN}_{t-i}+\sum_{i=0}^{s} \delta_{5 i} \mathrm{UR}_{t-i}+\sum_{i=0}^{w} \delta_{6 i} \mathrm{OPN}_{t-i}+\varepsilon_{t}
\end{aligned}
$$

The orders of lags in the ARDL models are selected using two criteria AIC and SBIC. The short run association among the variables are estimated considering the following error correction model:

$$
\begin{aligned}
\Delta \mathrm{GMSL}_{t}= & \psi_{0}+\sum_{i=1}^{m} \psi_{1 i} \Delta \mathrm{GMSL}_{t-i}+\sum_{i=0}^{p} \psi_{2 i} \Delta \mathrm{TEM}_{t-i}+\sum_{i=0}^{q} \psi_{3 i} \Delta \mathrm{CO}_{2_{t-i}} \\
& +\sum_{i=0}^{r} \psi_{4 i} \Delta \mathrm{EN}_{t-i}+\sum_{i=0}^{s} \psi_{5 i} \Delta \mathrm{UR}_{t-i}+\sum_{i=0}^{w} \psi_{6 i} \Delta \mathrm{OPN}_{t-i} \\
& +\lambda \mathrm{ECM}_{t-1}+u_{t}
\end{aligned}
$$

where the error correction term $\mathrm{ECM}_{t-1}$ is obtained from the following cointegration equation:

$$
\begin{aligned}
\mathrm{ECM}_{t}= & \mathrm{GMSL}_{t}-\delta_{0}-\sum_{i=1}^{m} \delta_{1 i} \mathrm{GMSL}_{t-i}-\sum_{i=0}^{p} \delta_{2 i} \mathrm{TEM}_{t-i}-\sum_{i=0}^{q} \delta_{3 i} \mathrm{CO}_{2 t-i} \\
& -\sum_{i=0}^{r} \delta_{4 i} \mathrm{EN}_{t-i}-\sum_{i=0}^{s} \delta_{5 i} \mathrm{UR}_{t-i}-\sum_{i=0}^{w} \delta_{6 i} \mathrm{OPN}_{t-i}
\end{aligned}
$$

In this case the parameter $\lambda$ represents the speed of adjustment for shortrun to reach in the long-run equilibrium. The estimated long-run and also the short-run effects of temperature, carbon dioxide emissions, energy consumption, urbanization and trade openness on global mean sea level are given below in Table 6 and in Table 7.

From estimated results in Table 7, it is found that in the short-run the variables temperature, carbon dioxide emissions, and urbanization have significant positive effects while energy consumption and trade openness have significant negative effects on global mean sea level at any significance level, the coefficient of ECM $(-1)$ is statistically significant at any significance level, indicates that speed of adjustment for short-run to research in the long-run equilibrium is

Table 6. Long-run coefficients.

\begin{tabular}{ccccc}
\hline Dependent Variable GMSL & Coefficient & Std. Error & t-Test & Probability \\
\hline Constant & $-336.6589^{*}$ & 13.4304 & -25.0667 & $\leq 0.0001$ \\
$\mathrm{TEM}$ & $12.1979^{*}$ & 2.0080 & 6.0747 & $\leq 0.0001$ \\
$\mathrm{CO}_{2}$ & $25.9270^{*}$ & 2.6369 & 9.8323 & $\leq 0.0001$ \\
$\mathrm{EN}$ & $-0.0502^{* *}$ & 0.0230 & -2.1823 & 0.0291 \\
$\mathrm{UR}$ & $4.61805^{*}$ & 0.8770 & 5.2658 & $\leq 0.0001$ \\
$\mathrm{OPN}$ & 0.2399 & 0.28183 & 0.85104 & 0.39474 \\
\hline
\end{tabular}

*: indicates significant at any significance level, ${ }^{* *}$ : indicates significant at $5 \%$ level. 
Table 7. Short-run coefficients.

\begin{tabular}{ccccc}
\hline Dependent Variable $\Delta$ GMSL & Coefficient & Std. Error & t-Test & Probability \\
\hline Constant & 0.2743 & 0.6913 & 0.3967 & 0.6936 \\
$\Delta$ TEM & $5.3320^{*}$ & 0.4893 & 10.8981 & $\leq 0.0001$ \\
$\Delta \mathrm{CO}_{2}$ & $6.2745^{*}$ & 1.4695 & 4.2699 & $\leq 0.0001$ \\
$\Delta \mathrm{EN}$ & $-0.01077^{*}$ & 0.0027 & -3.9890 & $\leq 0.0003$ \\
$\Delta \mathrm{UR}$ & $5.09985^{*}$ & 1.8009 & 2.8319 & $\leq 0.0071$ \\
$\Delta \mathrm{OPN}$ & $-0.4908^{*}$ & 0.1205 & -4.0718 & $\leq 0.0002$ \\
ECM\{-1\} & $-0.6652^{*}$ & 0.0297 & -22.3874 & $\leq 0.0001$ \\
\hline Sensitivity Analysis & & Diagnostic Test Results & Probability \\
\hline LM Test for Autocorrelation & 0.031871 & 0.8583 \\
LM test for Heteroscedasticity & 4.2363 & 0.5159 \\
ARCH Test & 0.5072 & 0.4764 \\
Misspecification Test & 2.2917 & 0.1375 \\
JB Test for Normality of Errors & 1.9903 & 0.3695 \\
\hline
\end{tabular}

*: indicates significant at any significance level.

statistically significant. The coefficient of error correction term is -0.6652 with the expected sign, suggesting that when global mean sea level is above or below its equilibrium level, it adjusts about $66.52 \%$ within the first year. Thus the full convergence process to its equilibrium level takes only less than two years. Thus the speed of adjustment is significantly faster in the case of any shock to the global mean sea level equation.

Also from the estimated results in Table 6, it is found that in the long-run the variables temperature, carbon dioxide emissions, and urbanization have significant positive effects on global mean sea level at any significance level but the variable energy consumption has significant negative effects at $5 \%$ significance level. Since the long-run effects of the variables temperature, and carbon dioxide emissions are higher than short-run effects means that over time higher temperature, and carbon dioxide emissions will increase global mean sea level rapidly.

Sensitivity Analysis: Diagnostic tests for serial correlation, autoregressive conditional heteroscedasticity, heteroscedasticity, and non-normal errors are conducted and the results are reported in Table 6. The test results indicate that there is no evidence of serial correlation, and there is no problem of heteroscedasticity. Also the autoregressive conditional heteroscedasticity is not present in the shortrun model. The test results also support that there is no problem of normality of random error terms in Equation (10).

\subsection{CUSUM and CUSUMSQ Tests}

The stability of the long-run parameters together with the short-run movements for the equations is examined using cumulative sum (CUSUM) and cumulative 

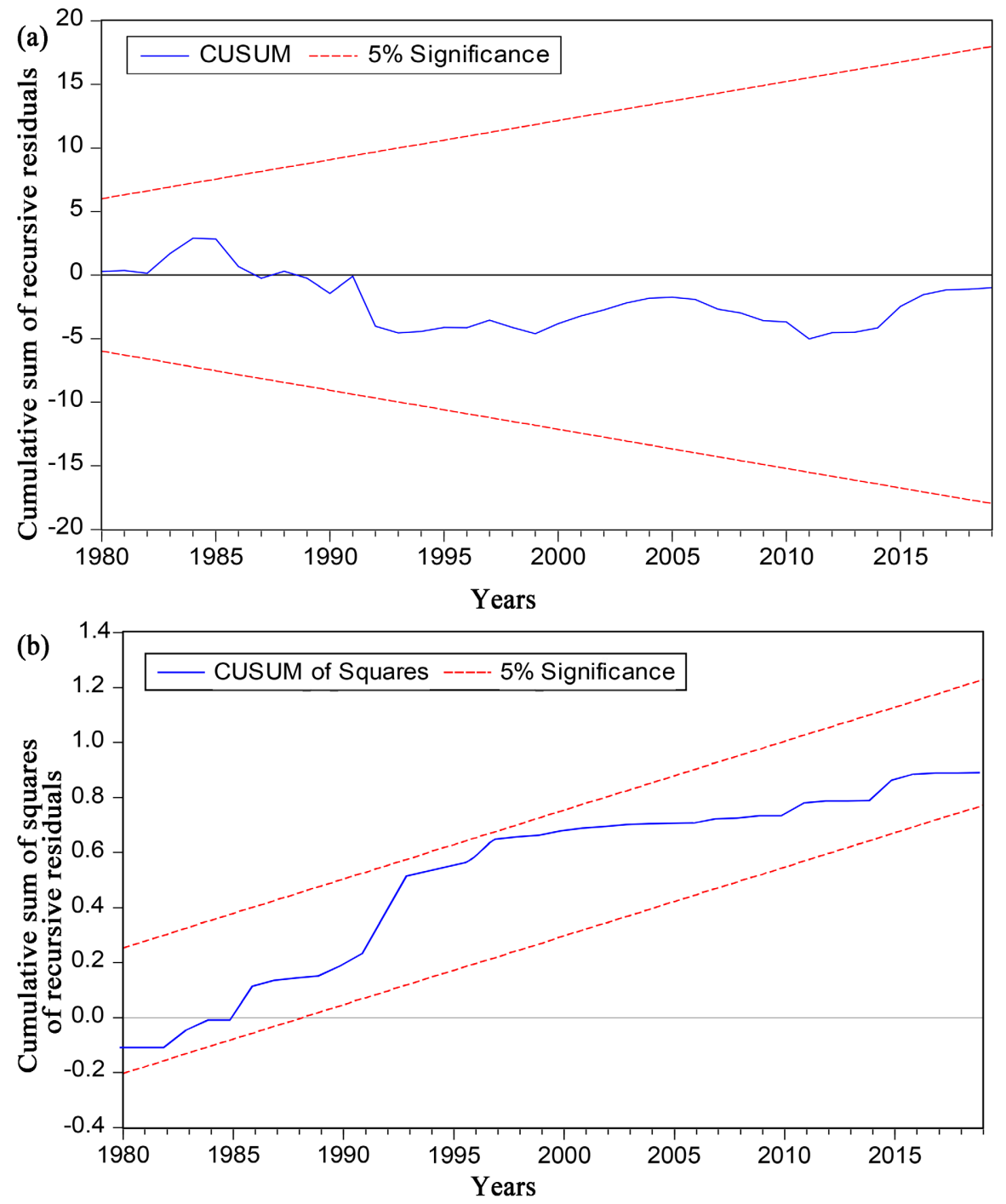

Figure 4. (a) Plot of Cumulative Sum of Recursive Residuals. The straight lines represent critical bounds at 5\% significance level; (b) Plot of Cumulative Sum of Squares of Recursive Residuals. The straight lines represent critical bounds at $5 \%$ significance level.

sum of squares (CUSUMSQ) tests proposed by Borensztein et al. (1998). The related graphs of these tests are presented below in Figure 4(a) and Figure 4(b).

From Figure 4(a) and Figure 4(b), it can be seen that the CUSUM and CUSUMSQ tests results are within the critical bounds implying that all coefficients in the error correction model are stable. Therefore the preferred GMSL model can be used for policy formulation and decision making purposes, such that the impact of policy changes considering the explanatory variables of GMSL equation will not cause major distortion in GMSL, since the parameters in this equation seem to follow a stable pattern during the estimation period.

\subsection{Impulse Response Analysis}

Impulse response functions are estimated in order to find response of one variable due to shock in another variable for the next 10 years. The responses of the 
variables TEM, $\mathrm{CO}_{2}$, EN, UR and OPN with respect to one standard deviation shock in the variable GMSL are depicted in Figure 5.

From Figure 5, it can be said that with respect to one standard deviation the variable TEM responds positively in the $1^{\text {st }}$ year and then negatively $2^{\text {nd }}$ year and then positive response for the next eight years; the variable $\mathrm{CO}_{2}$ responds negatively in the $1^{\text {st }}$ year, positively in the $2^{\text {nd }}$ year again negatively in the $3^{\text {rd }}$ year and then positive response afterward, the variable EN responds positively in next 3 years and then negatively in the next 3 years and then positive response afterwards; the variable UR responds negatively in the next four years and then positive response afterwards and the variable OPN responds positively for the next
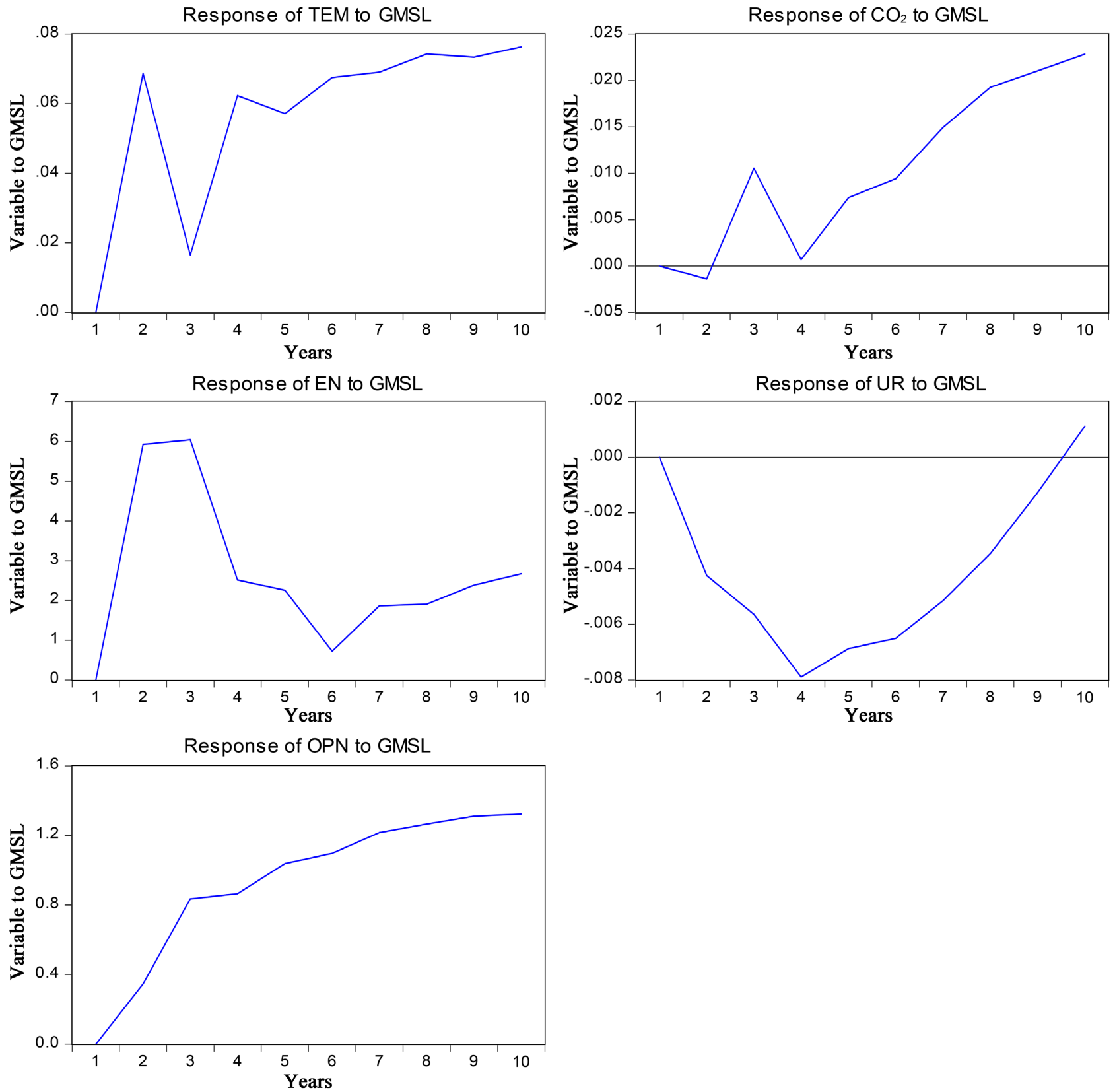

Figure 5. Response of TEM, $\mathrm{CO}_{2}$, EN UR and OPN in GMSL. 
10 years in the variable global mean sea level (GMSL).

\section{Conclusion and Policy Implications}

This paper attempts to investigate empirically the dynamic cointegration and causal relationships between temperature (TEM), carbon dioxide emissions $\left(\mathrm{CO}_{2}\right)$, energy consumption (EN), urbanization, (UR), trade openness (OPN) and global mean sea level (GMSL) using time series data from 1970-2019 and also to find the long-run and short-run impacts of these variables on GMSL. The investigation procedure involves the following steps. At the first step, the ADF, PP and KPSS tests are applied to investigate the unit root problem in each problem. The tests results support (see Table 3 ) that all the variables are integrated of order 1. Since all the variables are integrated of order 1 , thus there is a cointegration relationship among the variables.

Therefore at the second step, the bounds testing approach is applied in order to examine the existence of long-run cointegration relationship between GMSL and its determinants. The test results support (see Table 4) that there exist one cointegration equation when GMSL is the dependent variable. This implies that the explanatory variables TEM, $\mathrm{CO}_{2}, \mathrm{EN}$, UR and OPN are coalescing with inflation to achieve their steady-state equilibrium in the long-run, although deviation may occur in the short-run. The cointegration relationship indicates the existence of causal relationships between variables but it does not indicate the direction of causal relationship between variables. Therefore it is common to test for detecting the causal relationships between variables using the Engle and Granger test procedure. Thus at the third step the Granger F-test is applied to VECM to investigate the causal relationships between different pairs of variables. The Granger causality test results support (see Table 5 ) that the short-run unidirectional causalities are running from carbon dioxide emissions and energy consumption to global mean sea level, from energy consumption and trade openness to carbon dioxide emissions and from trade openness to energy consumption. It has also been found that the ECM $(-1)$ is statistically significant at any significance level when GMSL is treated as endogenous variable indicating that there exists a long-run relationship among the variables in the form of Equation (1). Finally, short-run and long-run effects of TEM, $\mathrm{CO}_{2}, \mathrm{EN}$, UR and OPN on inflation are estimated. The short-run equation is estimated using WLS method due to the heteroscedastic problem and the long-run equation is estimated using the GMM method. From the estimated results (see Table 6) it is found that in the shortrun the variables, TEM, $\mathrm{CO}_{2}$ and UR have significant positive effects while EN and OPN have significant negative effects on GMSL, the coefficient of ECM $(-1)$ is statistically significant, indicates that speed of adjustment for short-run to research in the long-run equilibrium is statistically significant. The coefficient of error correction term is -0.6652 , suggesting that when global mean sea level is above or below its equilibrium level, it adjusts about $66.52 \%$ within the first year. Thus the full convergence process to its equilibrium level takes only less than 
two years. Thus the speed of adjustment is significantly faster in the case of any shock to the global mean sea level equation. Also from the estimated results (see Table 7), it is found that in the long-run the variables TEM, $\mathrm{CO}_{2}$, and UR have significant positive effects but the variable EN has significant negative effects on GMSL. Since the long-run effects of the variables temperature, and carbon dioxide emissions are higher than the short-run effects means that over time higher temperature, and carbon dioxide emissions will increase global mean sea level rapidly. The diagnostic tests results (see Table 7) indicate that there is no evidence of serial correlation, heteroscedasticity and autoregressive conditional heteroscedasticity problems in the short-run model (10). The test results also support that there is no problem of normality of random error terms in Equation (10). The CUSUM and CUSUMSQ tests results suggest the policy changes considering the explanatory variables of GMSL equation will not cause major distortion.

Also in this paper the response functions are estimated with respect to one standard deviation shock in order to find the responses of the variables TEM, $\mathrm{CO}_{2}$, EN, UR and OPN in the variable GMSL for the next 10 years. From the estimated results it is found that the variables TEM, $\mathrm{CO}_{2}$, UR and OPN have positive responses while the variable EN responds negatively in the variable GMSL (see Figure 5) for the next 10 years.

From the analytical results the following points should be implemented to improve environmental quality as a results the world will be free from different types of natural disasters and the people in this globe can live with great happiness. Since the variables temperature, carbon dioxide emissions and urbanization play significant positive role both in short-run and long-run on global mean sea level, thus the global political leaders have to formulate new policies to reduce global warming, green houses gases and urbanization. They have to formulate policies to change human activities which guided to change human behaviors, technologies and policy formulations that encourage minimum waste and smatter use of our scarce resources. For example, improvements to energy efficiency and vehicle fuel economy, increases in wind and solar power, biofuels from organic waste, setting a tax on carbon dioxide emissions, protecting existing forests, plantation of new trees, and improving access, reducing poverty, income inequality for the people of rural and coastal areas which may play significant role to reduce global warming, the amount of carbon dioxide and urbanization. As a result the environmental quality will be improved and we all the people can live in this globe without fear of natural disasters and with great happiness.

\section{Conflicts of Interest}

The author declares no conflicts of interest regarding the publication of this paper.

\section{References}

Anthoff, D., Nicholls, R. J., \& Richard, S. J. T. (2010). The Economic Impact of Substantial Sea Level Rise. Mitigation and Adaptation Strategies for Global Change, 15, 321-335. 
https://doi.org/10.1007/s11027-010-9220-7

Asian Development Bank (ADB) (2013). The Economics of Climate Change in the Pacific. Asian Development Bank.

Borensztein, E., De Gregorio, J., \& Lee, J. W. (1998). How Does FDI Affect Economic Growth? Journal of International Economics, 45, 115-135. https://doi.org/10.1016/S0022-1996(97)00033-0

Burke, M., Hsiang, S. M., \& Miguel, E. (2015). Global Non-Linear Effect of Temperature on Economic Production. Nature, 527, 235-239. https://doi.org/10.1038/nature15725

Church, J. A., \& Neil, J. W. (2011). Sea Level Rise from the Late 19th to the Early 21st Century. Surveys in Geophysics, 32, 585-602. https://doi.org/10.1007/s10712-011-9119-1

Church, J. A., Clark, P. U., Cazenave, A., Gregory, J. M., Jevrejeva, S., Levermann, A. et al. (2013). Sea-Level Rise by 2100. Science, 342, 1445. https://doi.org/10.1126/science.342.6165.1445-a

Dell, M., Jones, B. F., \& Benjamin, A. O. (2012). Temperature Shocks and Economic Growth: Evidence from the Last Half Century. American Economic Journal: Macroeconomics, 4, 66-95. https://doi.org/10.1257/mac.4.3.66

Diaz, D. B. (2016). Estimating Global Damages from Sea Level Rise with the Coastal Impact and Adaptation Model (CIAM). Climatic Change, 137, 143-156.

https://doi.org/10.1007/s10584-016-1675-4

Ebru, K., Ian, R. Y., Ranasinghe, R., Muis, S., Nicholls, R. J., Lincke, D., \& Hinkel, J. (2020). Projections of Global-Scale Extreme sea Levels and Resulting Episodic Coastal Flooding over the 21st Century. Scientific Report, 10, Article No. 11629. https://doi.org/10.1038/s41598-020-67736-6

Ericson, J. P., Charles, J., Vorosmarty, S., Lawrence, D., Larry, G. W., \& Michel, M. (2006). Effective Sea Level Rise and Deltas: Causes of Change and Human Dimension Implications. Global Planet Change, 50, 63-82.

https://doi.org/10.1016/j.gloplacha.2005.07.004

Frederikse, T., Landerer, F., Caron, L., Adhikari, S., Parkes, D., Humphrey, W. V., Dangendoff, S., Hogarth, P., Zanna, L., Cheng, L., \& Wu, Y.-H. (2020). The Causes of SeaLevel Rise since 1900. Nature, 584, 393-397. https://doi.org/10.1038/s41586-020-2591-3

Granger, C. W. J., \& Newbold, P. (1974). Spurious Regression in Econometrics. Journal of Econometrics, 2, 111-120. https://doi.org/10.1016/0304-4076(74)90034-7

Hallegatte, S. (2012). A Framework to Investigate the Economic Growth Impact of Sea Level Rise. Environmental Research Letters, 7, Article ID: 015604. https://doi.org/10.1088/1748-9326/7/1/015604

Horton, B. P., Khan, N. S., Cahill, N., Lee, J. S. H., Shaw, T. A., Garner, A. J. et al. (2020). Estimating Global Mean Sea-Level Rise and Its Uncertainties by 2100 and 2300 from an Expert Survey. NPJ Climate and Atmospheric Science, 3, Article No. 18. https://doi.org/10.1038/s41612-020-0121-5

Marcos, M., \& Woodworth, P. L. (2017). Spatiotemporal Changes in Extreme Sea Levels along the Coasts of the North Atlantic and the Gulf of Mexico: Extreme Sea Level Changes. Journal of Geophysical Research: Oceans, 122, 7031-7048.

https://doi.org/10.1002/2017JC013065

Milne, G. A., Gehrels, W. R., Hughes, C. W., \& Tamisiea, M. E. (2009). Identifying the Causes of Sea-Level Change. Nature Geoscience, 2, 471-478.

https://doi.org/10.1038/ngeo544

Narayan, P. K. (2005). The Saving and Investment Nexus for China: Evidence from Cointe- 
gration Tests. Applied Economics, 37, 1979-1990.

https://doi.org/10.1080/00036840500278103

Nerem, R. S., Beckley, B. D., Fasullo, J. T., Hamlington, D. B., Masters, D., \& Mitchum, G. T. (2018). Climate-Change-Driven Accelerated Sea-Level Rise Detected in the Altimeter Era. Proceedings of the National Academy of Sciences of the United States of America, 115, 2022-2025. https://doi.org/10.1073/pnas.1717312115

Nicholls, R. J., \& Cazenave, A. (2010). Sea-Level Rise and Its Impact on Coastal Zones. Science, 328, 1517-1520. https://doi.org/10.1126/science.1185782

Pesaran, M. H., Shin, Y., \& Smith, R. J. (2001). Bound Testing Approaches to the Analysis of Level Relationships. Journal of Applied Econometrics, 16, 289-326.

https://doi.org/10.1002/jae.616

Phillips, P. C. B., \& Perron, P. (1987). Testing for a Unit Root in Time Series Regression. Biometrika, 75, 335-346. https://doi.org/10.1093/biomet/75.2.335

Rhein, M., Rintoul, S. R., Aoki, S., Campos, E., Chambers, D., Feely, R. A., Gulev, S., Johnson, G. C., Josey, S. A., Kostianoy, A. et al. (2013). Observations: Ocean. In T. F. Stocker, D. Qin, G.-K. Plattner, M. Tignor, S. K. Allen, J. Boschung, A. Nauels, Y. Xia, V. Bex, \& P. M. Midgley (Eds.), Climate Change 2013: The Physical Science Basis. Contribution of Working Group I to the Fifth Assessment Report of the Intergovernmental Panel on Climate Change (pp. 255-315). Cambridge University Press.

Ruben, C. A., \& Minsoo, L. (2017). Impacts of Sea Level Rise on Economic Growth in Developing Asia. ADB Economic Working Paper Series, No. 507, Asian Development Bank.

Stock, J. H., \& Watson, M. W. (1988). Testing for Common Trends. Journal of the American Statistical Association, 83, 1097-1107. https://doi.org/10.1080/01621459.1988.10478707

Vitousek, S., Barnard, P., Fletcher, C., Frazer, N., Erikson, L., \& Storlazzi, C. D. (2017). Doubling of Coastal Flooding Frequency within Decades Due to Sea-Level Rise. Scientific Reports, 7, Article No. 1399. https://doi.org/10.1038/s41598-017-01362-7

Vousdoukas, M. I., Mentaschi, L., Voukouvalas, E., Verlaan, M., Jevrejeva, S., Jackson, L. P. et al. (2018). Global Probabilistic Projections of Extreme Sea Levels Show Intensification of Coastal Flood Hazard. Nature Communications, 9, Article No. 2360. https://doi.org/10.1038/s41467-018-04692-w

Woodworth, P. L., Hunter, J. R., Marcos, M., Caldwell, P., Menendez, M., \& Haigh, I. (2017). Towards a Global Higher-Frequency Sea Level Dataset. Geoscience Data Journal, 3, 50-59. https://doi.org/10.1002/gdj3.42 